\title{
PENGEMBANGAN SOAL TEST DIGITAL MATAKULIAH ASESMEN DAN EVALUASI MENGGUNAKAN APLIKASI WONDERSHARE
}

\author{
Agus Adiarta1, Dewa Gede Hendra Divayana² \\ 1Program Studi Pendidikan Teknik Elektro, Universitas Pendidikan Ganesha \\ 2Program Studi Pendidikan Teknik Informatika, Universitas Pendidikan Ganesha \\ Email Korespondensi: hendra.divayana@undiksha.ac.id
}

\begin{abstract}
ABSTRAK
Penelitian ini mempunyai tujuan utama untuk memperkenalkan langkah-langkah membuat soal test berformat digital berbantuan aplikasi gratisan yang bernama wondershare. Hal ini menjadi penting untuk diketahui karena saat ini masih banyak pendidik yang belum mampu membuat sendiri soal test berformat digital yang valid, praktis, dan variatif. Pendekatan yang digunakan dalam penelitian adalah pengembangan. Metode yang digunakan dalam penelitian ini adalah Research \& Development, dengan model Borg \& Gall dengan 10 tahapan pengembangan, diantaranya: penelitian dan pengumpulan data lapangan, merencanakan penelitian, pengembangan desain, uji coba awal, revisi hasil uji coba awal, uji coba lapangan, revisi hasi uji coba lapangan, uji coba pemakaian, revisi produk akhir, serta desiminasi dan implementasi produk akhir. Fokus tahapan pengembangan pada penelitian ini adalah pada tahapan penelitian dan pengumpulan data lapangan, perencanaan penelitian, pengembangan desain, dan uji coba awal. Alat yang digunakan dalam pengumpulan data berupa kuesioner. Responden yang dilibatkan dalam uji coba awal sebanyak 10 orang. Teknik yang digunakan untuk menganalisis hasil penelitian adalah teknik deskriptif kuantitatif dengan membandingkan persentase efektivitas hasil uji cob awal dengan tabel efektivitas yang mengacu skala lima. Hasil penelitian ini menunjukkan adanya 9 model soal test digital variatif yang dapat dibuat menggunakan aplikasi wondershare khususnya untuk matakuliah Asesmen dan Evaluasi dengan tingkat efektivitas sebesar $88,4 \%$ sehingga termasuk kategori baik.
\end{abstract}

Kata kunci: Soal Test, Digital, Asesmen dan Evaluasi, Wondershare

\begin{abstract}
This study has the main objective to introduce the steps to create a digital format test question assisted by a free application called Wondershare. This matter is important to note, because, at this time, there are still many educators who have not been able to make their digital format test questions that are valid, practical, and varied. The approach was used in the research was development. The method was used in this study was Research \& Development, with the Borg \& Gall model that consist of 10 stages of development, including: research and field data collection, planning research, design development, preliminary trials, revisions to the results of preliminary trials, field trials, revisions results of field trials, trials of use, revision of the final product, and also the dissemination and implementation of the final product. The focus of the development stage in this research was on the stage of research and field data collection, research planning, design development, and preliminary trials.

The tool was used in data collection in the form of a questionnaire. Respondents were involved in the initial trial were ten people. The technique was used to analyze the results of this study was a quantitative descriptive technique by comparing the effectiveness percentage of the initial test results with an effectiveness table that refers to a five's scale. The results of this study indicate the existence of 9 models of varied digital test question that could be made using the Wondershare application for the Assessment and Evaluation subject with an effectiveness level, was $88.4 \%$ so that it was included in the good category.
\end{abstract}

Keywords : Test Questions, Digital, Assessment and Evaluation, Wondershare 


\section{PENDAHULUAN}

Pada era revolusi industri 4.0 seperti saat ini, semua hal dalam kehidupan ini tidak bisa terpisahkan dari teknologi informasi. Hal ini diperkuat dari pernyataan Mintasih [1], Iswan dan Herwina [2], Prasetyo dan Trisyanti [3], Purwandini dan Irwansyah [4], Muslimin [5], Syamsuar dan Reflianto [6], yang pada prinsipnya sama yaitu menyatakan bahwa kehidupan saat ini tidak terlepas dari pengaruh kemajuan teknologi informasi, karena semua komponen penunjang kehidupan umat manusia telah mengalami perubahan dari bentuk konvensional ke digitalisasi melalui penerapan teknologi informasi. Teknologi informasipun secara spesifik juga sudah merambah ke berbagai hal dalam bidang pendidikan, mulai dari persiapan perangkat pembelajaran, pelaksanaan proses pembelajaran, sampai dengan evaluasi pembelajaran. Salah satu perangkat pembelajaran yang harus disiapkan oleh seorang guru pada era revolusi industri 4.0 ini adalah media pembelajaran yang berbasis teknologi informasi, misal: power point interaktif, video pembelajaran, dan lainnya. Saat proses pembelajaran, guru juga perlu menggunakan model pembelajaran berbasis ICT, misalkan blended learning, e-learning, dan lainnya. Bahkan pada tahap akhir pembelajaran yaitu evaluasi, guru juga perlu menggunakan ICT untuk memperoleh hasil penilaian yang objektif dan diproses dalam waktu yang cepat. Kendatipun pemanfaatan ICT dalam proses perencanaan dan pelaksanaan pembelajaran di sekolah sudah tampak berjalan dengan baik, namun tidak bisa dipungkiri bahwa masih banyak juga sekolah yang melakukan proses evaluasi secara tidak baik sehingga sulit dalam menentukan siswa yang memang benar-benar mempunyai kualitas pengetahuan yang tinggi. Oleh karena itu perlu kiranya menentukan terobosan baru untuk membuat test dengan variasi soal yang baik. Adapun bentuk test yang dapat dibuat adalah dalam bentuk test digital menggunakan aplikasi wondershare.

Mengacu pada permasalahan yang terjadi dan terobosan inovasi yang dilakukan untuk memecahkan permasalahan tersebut, maka tujuan penelitian ini adalah untuk mengetahui langkahlangkah pembuatan test digital menggunakan aplikasi wondershare. Adapun rumusan masalah penelitian ini adalah bagaimanakan langkah-langkah pembuatan test digital menggunakan aplikasi wondershare?

Penelitian ini dilatarbelakangi oleh hasil-hasil penelitian sebelumnya yaitu penelitian yang dilakukan oleh Putrawansyah, Zulkardi, dan Sardianto MS pada tahun 2016 [7] yang menunjukkan bahwa penggunaan buku digital berbasis android untuk menunjang pembelajaran perpindahan kalor telah memicu keefektifan proses pembelajaran pada sekolah menengah atas, sehingga hasil belajar siswa meningkat. Namun, kelemahan yang ditemukan dalam penelitian Putrawansyah, Zulkardi, dan Sardianto MS ialah belum mampu menyajikan soal-soal interaktif dan variatif dalam buku digital berbasis android tersebut. Penelitian yang dilakukan oleh Balan, Sudarmin, dan Kustiono pada tahun 2017 [8] menunjukkan penggunaan aplikasi adobe flash dalam membuat test berbasis komputer untuk tingkat SMK, sehingga menghasilkan test yang efektif, praktis, dan valid. Keterbatasan dalam penelitian ini adalah masih banyak guru yang belum fasih menggunakan aplikasi adobe flash, sehingga guru sulit dalam membuat test berbasis komputer secara mandiri untuk keperluan persiapan soal-soal bervariatif sejak dini yang diberikan kepada siswa guna melatih kemampuan mereka menggunakan komputer dalam menjawab soal test yang bervariasi. Penelitian yang dilakukan oleh Meryansumayeka, Virgiawan, dan Marlini pada tahun 2018 [9] menunjukkan bahwa aplikasi wondershare quiz creator dapat memudahkan guru dalam membuat kuis interaktif. Hal yang belum ditunjukkan dalam penelitian Meryansumayeka, Virgiawan, dan Marlini ini adalah langkah-langkah membuat kuis interaktif menggunakan aplikasi wondershare tersebut.

\section{METODE}

Pendekatan yang digunakan dalam penelitian ini adalah pengembangan. Metode yang digunakan yaitu R\&D dengan model Borg\&Gall yang terdiri dari 10 tahapan, diantaranya: (1) penelitian dan pengumpulan data lapangan, (2) perencanaan penelitian, (3) pengembangan desain, (4) uji coba awal, (5) revisi uji coba awal, (6) uji coba lapangan, (7) revisi hasi uji coba lapangan, (8) uji coba pemakaian, (9) revisi produk akhir, serta (10) desiminasi dan implementasi produk akhir. Dari 10 tahapan model Borg\&Gall tersebut, pada penelitian ini dibahas khusus terkait tahapan penelitian dan pengumpulan data lapangan, tahapan perencanaan penelitian, tahapan pengembangan desain, dan tahapan uji coba awal. Khususnya pada tahap pengembangan desain, soal test digital yang dibuat menggunakan aplikasi wondershare ini, mengikuti beberapa langkah, diantaranya: (1) pembuatan cover, (2) pembuatan template, (3) penyusunan butir soal, (4) pengaturan soal, dan (5) publikasi. Beberapa hal pokok yang disiapkan dalam pembuatan cover, diantaranya: judul cover, nama pembuat, deskripsi singkat tentang cover, dan gambar. Beberapa hal pokok yang disiapkan dalam 
pembuatan template, diantaranya: konsistensi model tamplate, warna background, dan tata letak soal. Beberapa hal pokok yang disiapkan dalam penyusunan butir, diantaranya: jenis soal, jumlah soal, dan konten soal. Beberapa hal pokok yang disiapkan dalam pengaturan soal, diantaranya: ukuran huruf, jenis huruf, pengacakan soal, pengacakan jawaban, pengaturan waktu kemunculan soal, pengaturan bobot penilaian soal untuk butir positif ataupun negatif, serta pengaturan passing grade. Beberapa hal pokok yang disiapkan dalam publikasi, diantaranya: publish secara online atau publish secara offline. Lokasi penelitian ini dilaksanakan pada prodi Pendidikan Teknik Elektro dan Pendidikan Teknik Informatika, Fakultas Teknik dan Kejuruan, Universitas Pendidikan Ganesha. Pihak yang dilibatkan dalam pengembangan soal test digital ini sebanyak 2 orang yaitu tim peneliti, responden uji coba awal sebanyak 20 orang mahasiswa (10 orang mahasiswa prodi pendidikan teknik elektro dan 10 orang mahasiswa prodi pendidikan teknik informatika). Dalam penelitian ini teknik pengumpulan data menggunakan kuesioner, sedangkan analisis datanya menggunakan deskriptif kuantitatif. Hasil analisis deskriptif kuantitatif pada penelitian ini didasarkan pada persentase efektifitas soal test digital yang mengacu pada tingkat pengkategorian efektivitas skala lima, yang selengkapnya ditunjukkan pada Tabel 1.

Tabel 1. Tingkat Pengkategorian Efektivitas Skala Lima

\begin{tabular}{|c|c|c|c|}
\hline No & $\begin{array}{c}\text { Persentase } \\
\text { Efektivitas }\end{array}$ & Kategori & Tindak Lanjut \\
\hline 1 & $0-54 \%$ & Sangat Kurang & Revisi \\
\hline 2 & $55-64 \%$ & Kurang & Revisi \\
\hline 3 & $65-79 \%$ & Cukup & Revisi \\
\hline 4 & $80-89 \%$ & Baik & Tidak Perlu Revisi \\
\hline 5 & $90-100 \%$ & Sangat Baik & Tidak Perlu Revisi \\
\hline
\end{tabular}

\section{HASIL DAN PEMBAHASAN}

Hasil penelitian ini mengacu pada tahapan-tahapan pengembangan model Borg\&Gall, khusus pada tiga tahapan yang telah dijelaskan pada metode penelitian di atas. Adapun hasil dan pembahasan rinci terkait hal tersebut dapat dijelaskan sebagai berikut.

\section{A. Hasil Penelitian dan Pengumpulan Data Lapangan}

Hasil penelitian dan pengumpulan data lapangan dalam penelitian ini berupa model soal dan contoh butir soal matakuliah Asesmen dan Evaluasi yang nantinya akan dimasukkan ke dalam aplikasi wondershare. Adapun model soal dan contoh butir soal matakuliah Asesmen dan Evaluasi yang dimaksudkan, selengkapnya ditunjukkan pada Tabel 2 berikut.

Tabel 2. Model Soal dan Contoh Butir Soal Matakuliah Asesmen dan Evaluasi Yang Dimasukkan Dalam Aplikasi Wondershare

\begin{tabular}{|c|c|c|}
\hline No & Model Soal & Butir Soal \\
\hline 1 & True/False & $\begin{array}{l}\text { CIPP kependekan dari Context-Input-Process-Product } \\
\circ \text { Benar } \\
\circ \text { Salah }\end{array}$ \\
\hline 2 & Multiple Choice & $\begin{array}{l}\text { Berikut ini yang bukan merupakan model evaluasi adalah... } \\
\circ \text { CIPP } \\
\circ \text { Countenance } \\
\circ \text { SAW } \\
\circ \text { CSE-UCLA } \\
\circ \text { Discrepancy }\end{array}$ \\
\hline 3 & Multiple Response & Pilihlah dari list berikut yang merupakan model evaluasi. \\
\hline
\end{tabular}




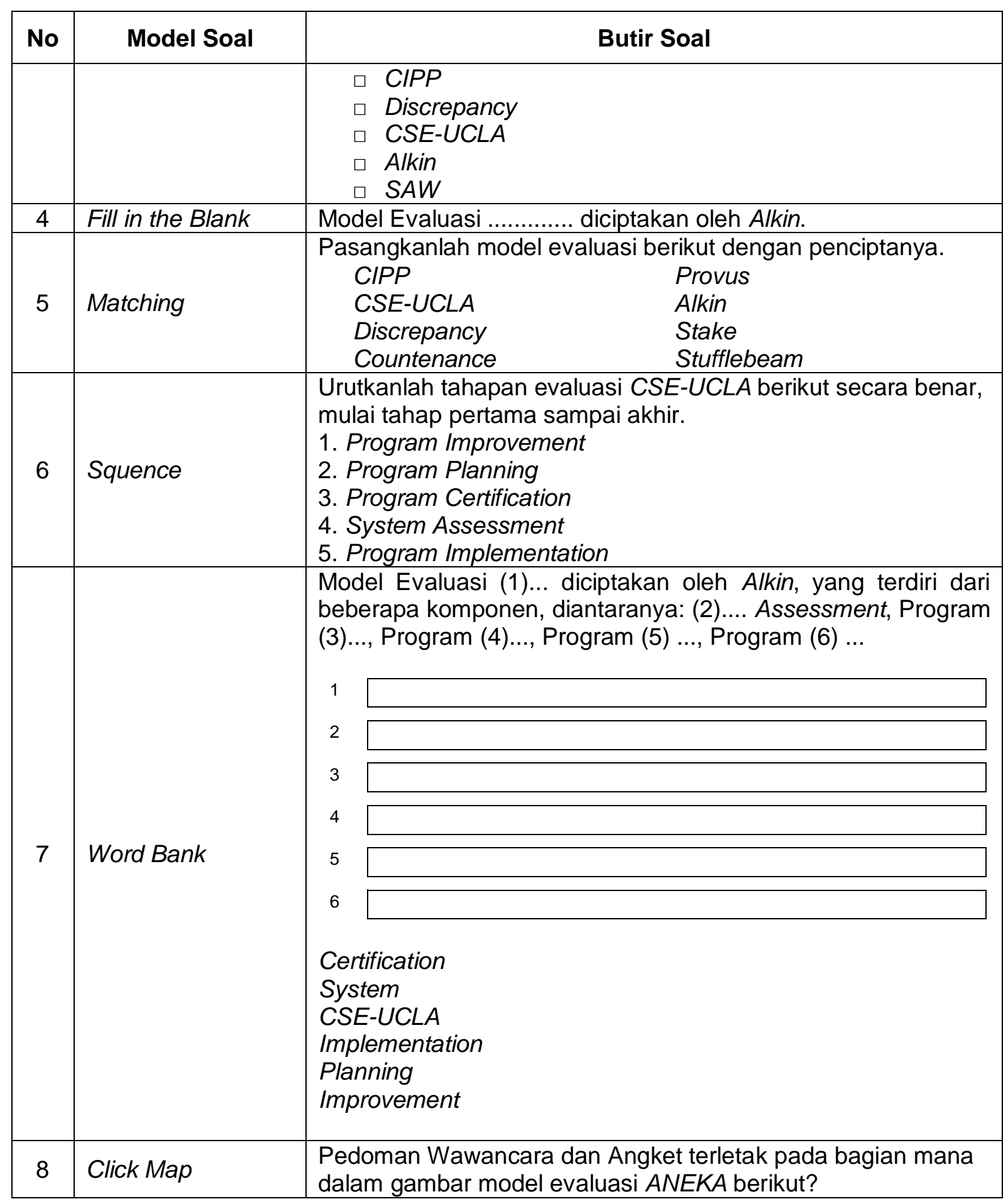




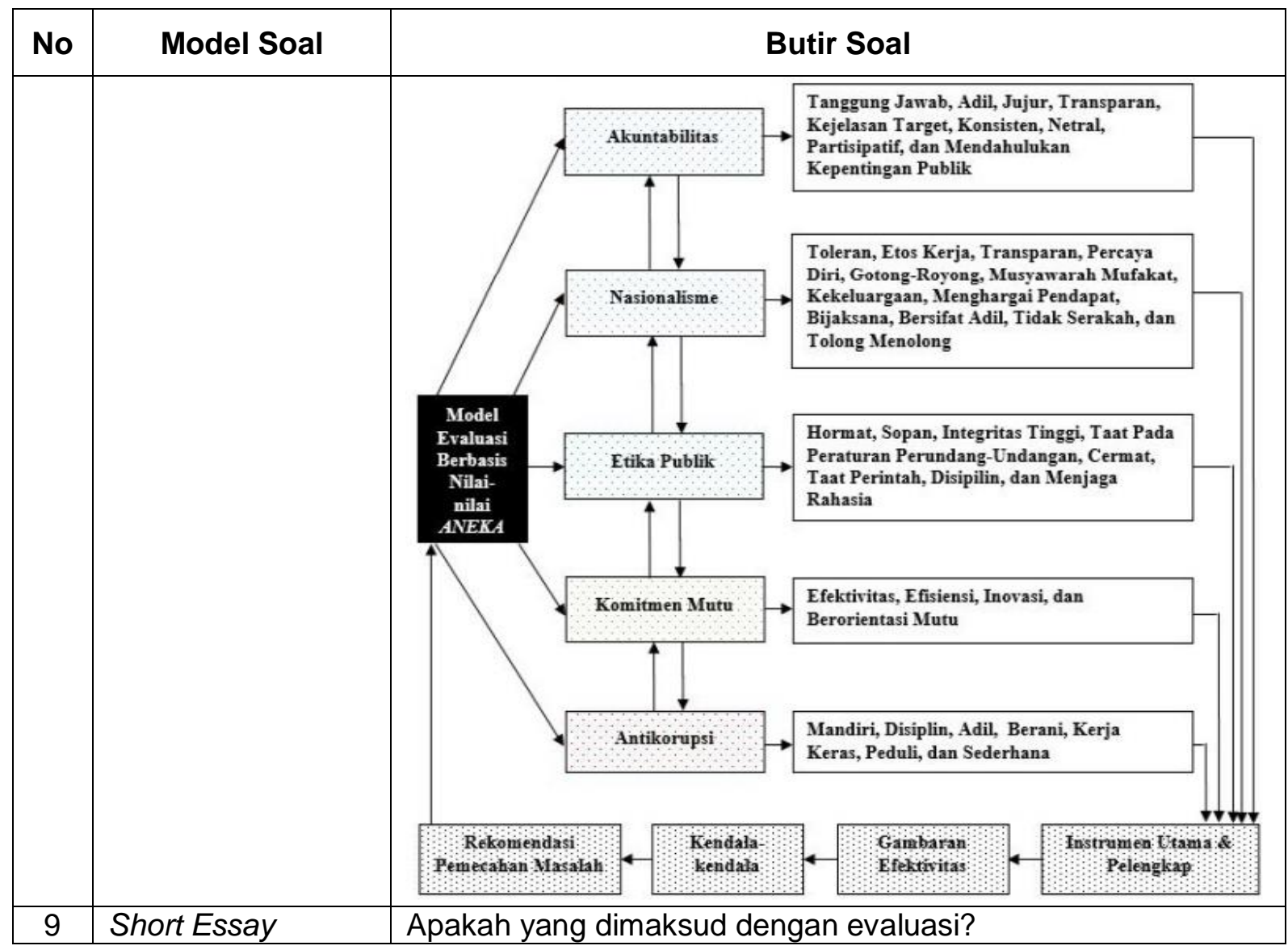

\section{B. Hasil Perencanaan Penelitian}

Adapun hasil dari tahapan ini berupa sumber daya manusia dan alokasi waktu yang direncanakan untuk menyelesaikan soal test digital menggunakan aplikasi wondershare. Adapun sumber daya manusia yang direncanakan terlibat dalam pembuatan soal test digital matakuliah Asesmen dan Evaluasi menggunakan aplikasi wondershare dapat dilihat pada Tabel 3, sedangkan alokasi waktu yang direncanakan dapat dilihat pada Tabel 4 .

Tabel 3. Sumber Daya Manusia yang Dilibatkan Dalam Pembuatan Soal Test Digital Matakuliah Asesmen dan Evaluasi Dengan Menggunakan Aplikasi Wondershare

\begin{tabular}{|c|l|c|}
\hline No & \multicolumn{1}{|c|}{ Bidang Keilmuan } & Jumlah \\
\hline 1 & Penelitian dan Evaluasi Pendidikan & 1 orang \\
\hline 2 & Pendidikan Teknik Informatika & 1 orang \\
\hline & Total & 2 orang \\
\hline
\end{tabular}

Tabel 4. Kebutuhan Waktu Dalam Pembuatan Soal Test Digital Matakuliah Asesmen dan Evaluasi Dengan Menggunakan Aplikasi Wondershare

\begin{tabular}{|c|l|c|}
\hline No & \multicolumn{1}{|c|}{ Kegiatan } & Waktu \\
\hline 1 & Pemilihan Butir Soal & 2 hari \\
\hline 2 & Pembuatan Design Aplikasi & 4 hari \\
\hline & Total & 6 hari \\
\hline
\end{tabular}




\section{Hasil Pengembangan Desain}

Dalam pengembangan desain soal test digital matakuliah Asesmen dan Evaluasi, diperoleh hasil pengembangan sesuai langkah-langkah pengembangan desain menggunakan aplikasi wondeshare[10]. Adapun selengkapnya terkait langkah-langkah pengembangan yang dimaksudkan dapat dijelaskan sebagai berikut.

\section{1) Pembuatan Cover}

Adapun salah satu tampilan cover test digital yang telah jadi dapat ditunjukkan pada Gambar 1. Cover test digital yang ditunjukkan pada Gambar 1 ini memvisualisasikan tampilan depan soal test digital untuk matakuliah Asesmen dan Evaluasi.

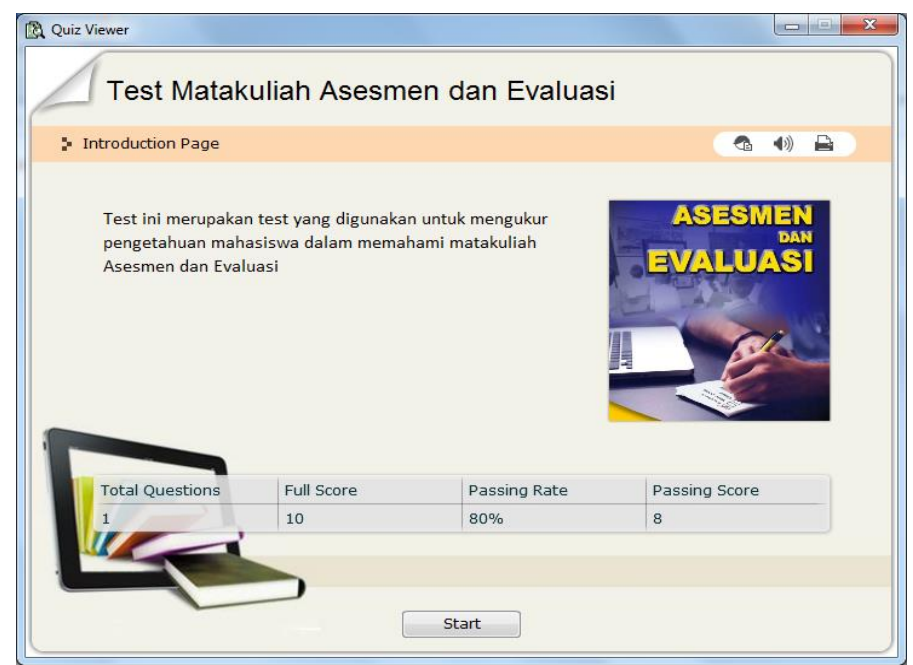

Gambar 1. Tampilan Cover Soal Test Digital Matakuliah Asesmen dan Evaluasi

\section{2) Pembuatan Template}

Salah satu tampilan template soal test digital yang telah jadi dapat ditunjukkan pada Gambar 2. Template test digital yang ditunjukkan pada Gambar 2 ini mengambil contoh yang sudah tersedia pada aplikasi wondershare.

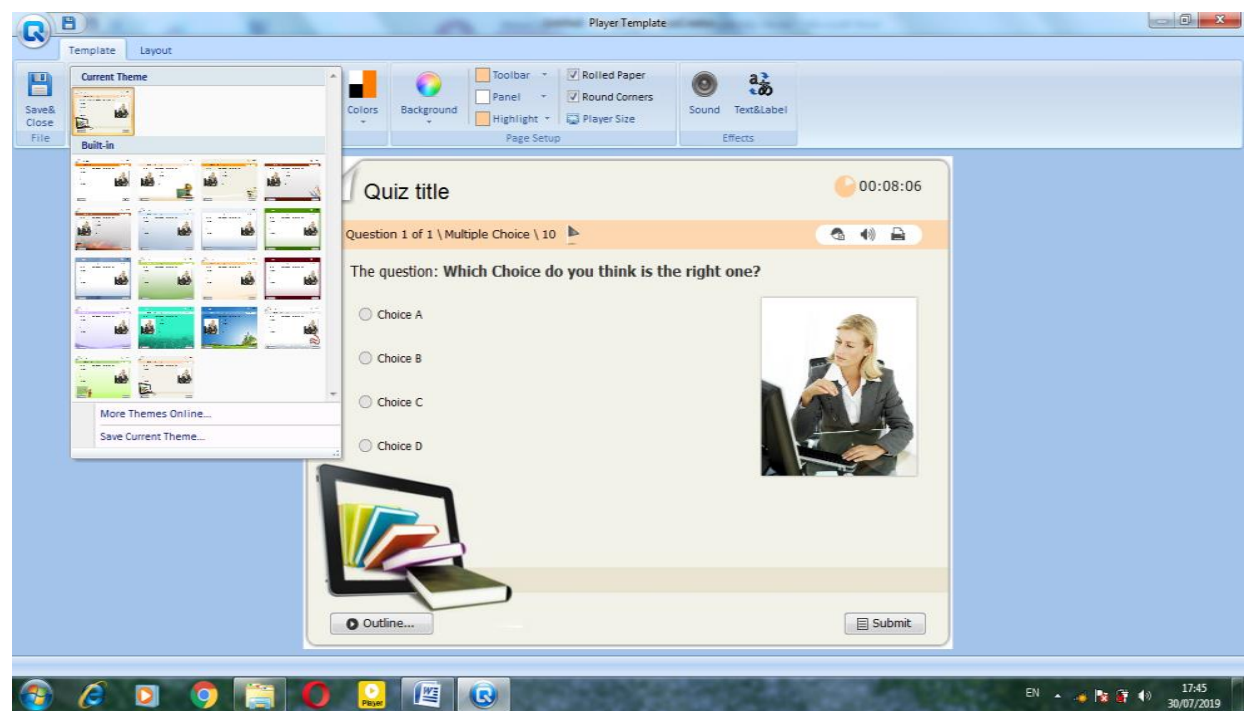

Gambar 2. Tampilan Template Soal Test Digital

\section{3) Penyusunan Butir Soal}

Terdapat 9 model soal yang dapat dibuat dengan menggunakan aplikasi wondershare. Kesembilan bentuk soal tersebut dapat ditunjukkan melalui beberapa contoh soal yang 
terkait dengan matakuliah Asesmen dan Evaluasi. Adapun selengkapnya tentang butir soal tersebut dapat ditunjukkan pada Gambar 3 sampai dengan Gambar 11.

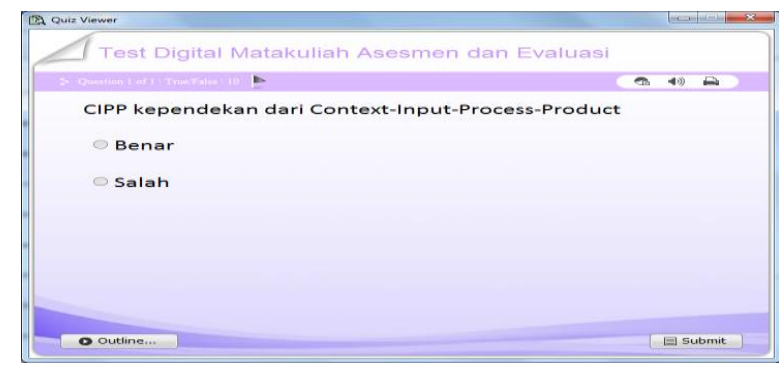

Gambar 3. Tampilan Soal True/False

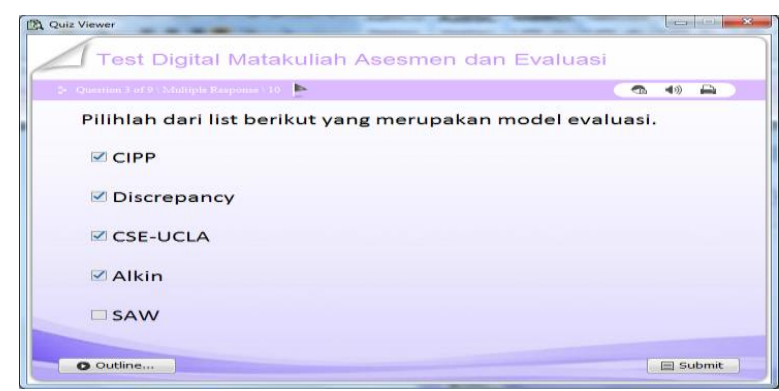

Gambar 5. Tampilan Soal Multiple Response

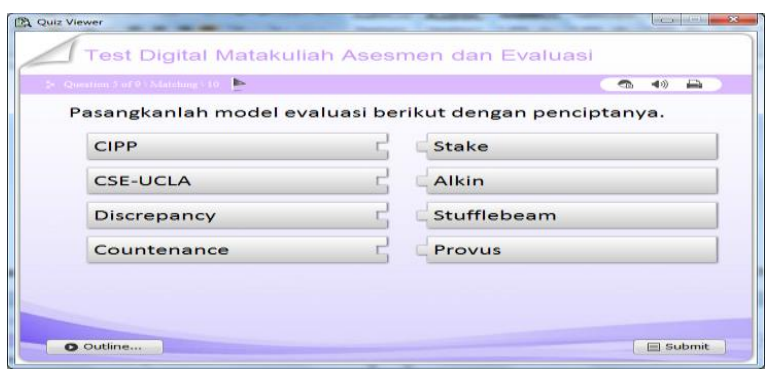

Gambar 7. Tampilan Soal Matching

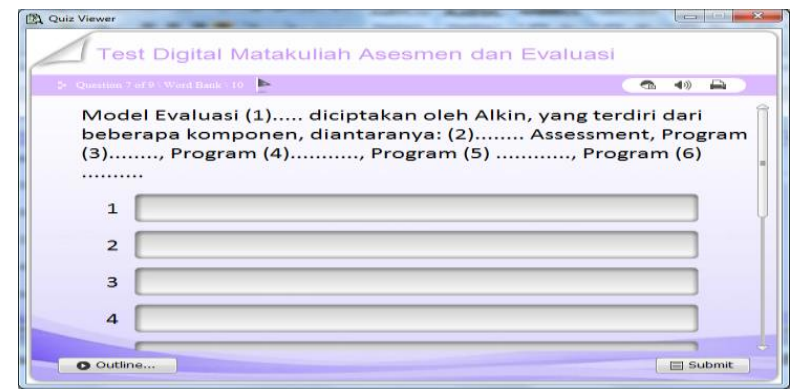

Gambar 9. Tampilan Soal Word Bank

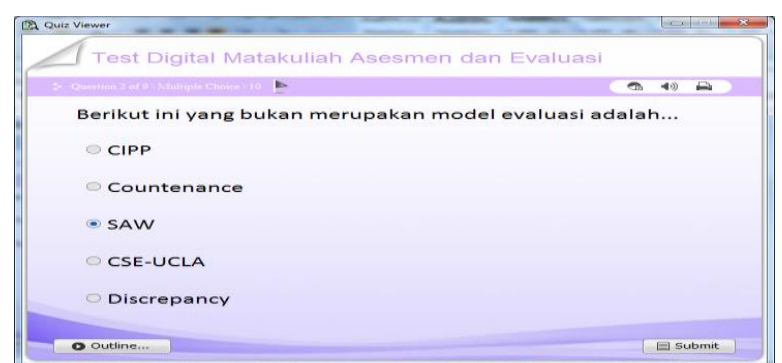

Gambar 4. Tampilan Soal Multiple Choice

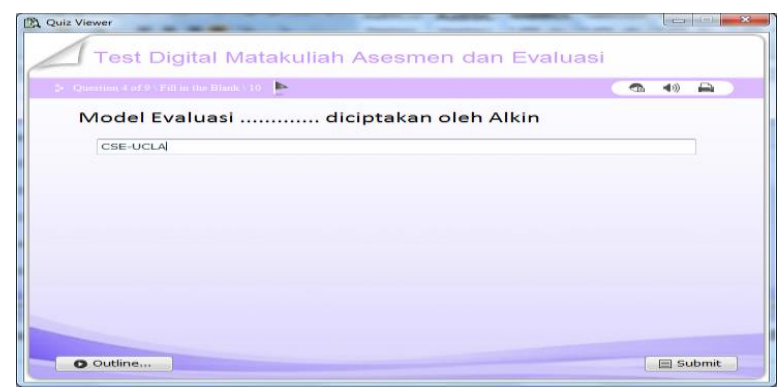

Gambar 6. Tampilan Soal Fill in the Blank

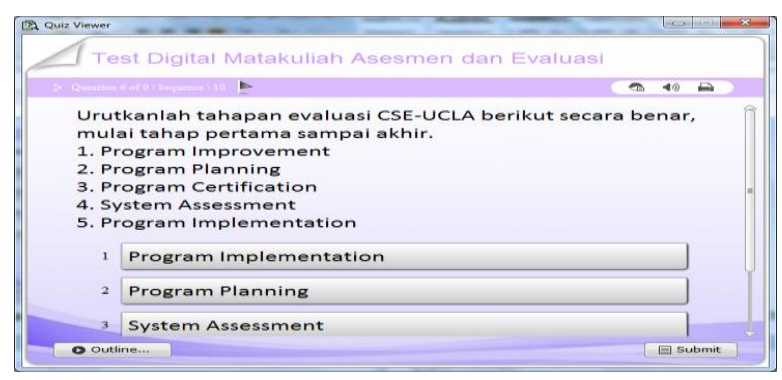

Gambar 8. Tampilan Soal Sequence

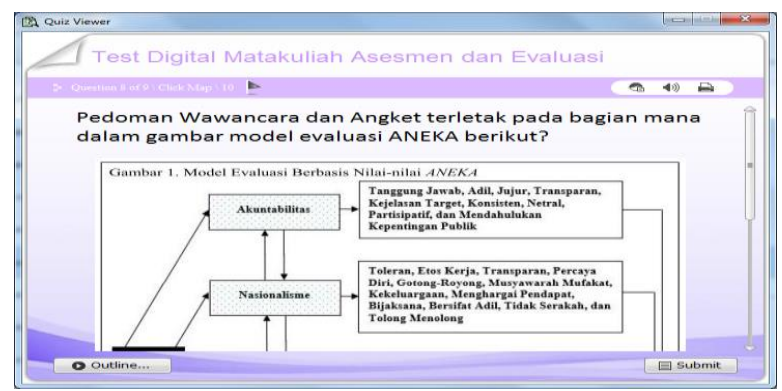

Gambar 10. Tampilan Soal Click Map 


\section{4) Pengaturan Soal}

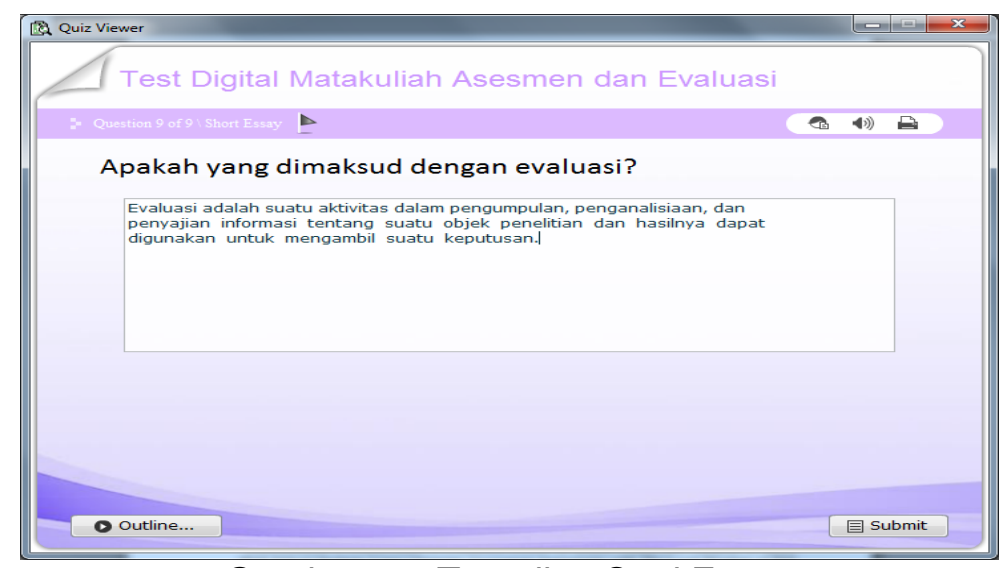

Gambar 11. Tampilan Soal Essay

Beberapa tampilan proses pengaturan soal, pengaturan waktu, dan passing grade test digital dapat ditunjukkan pada Gambar 12 dan 13. Adapun gambar-gambar yang dimaksud dapat ditunjukkan sebagai berikut.

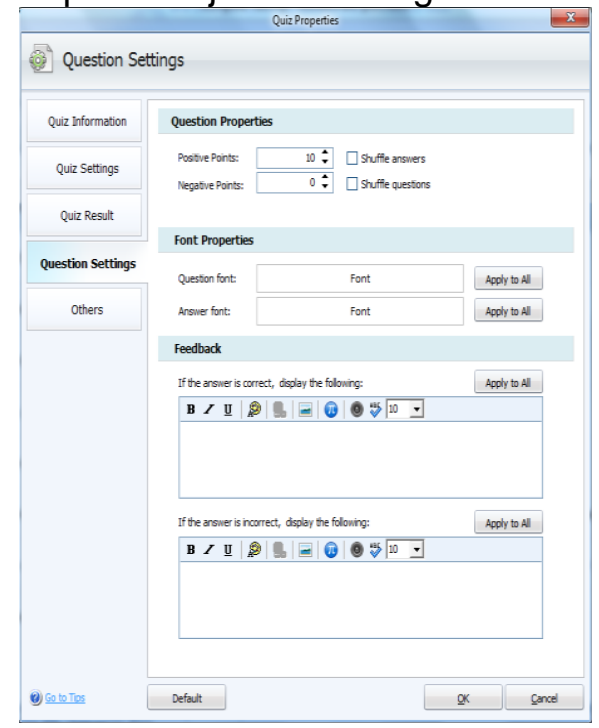

Gambar 12. Pengaturan Soal

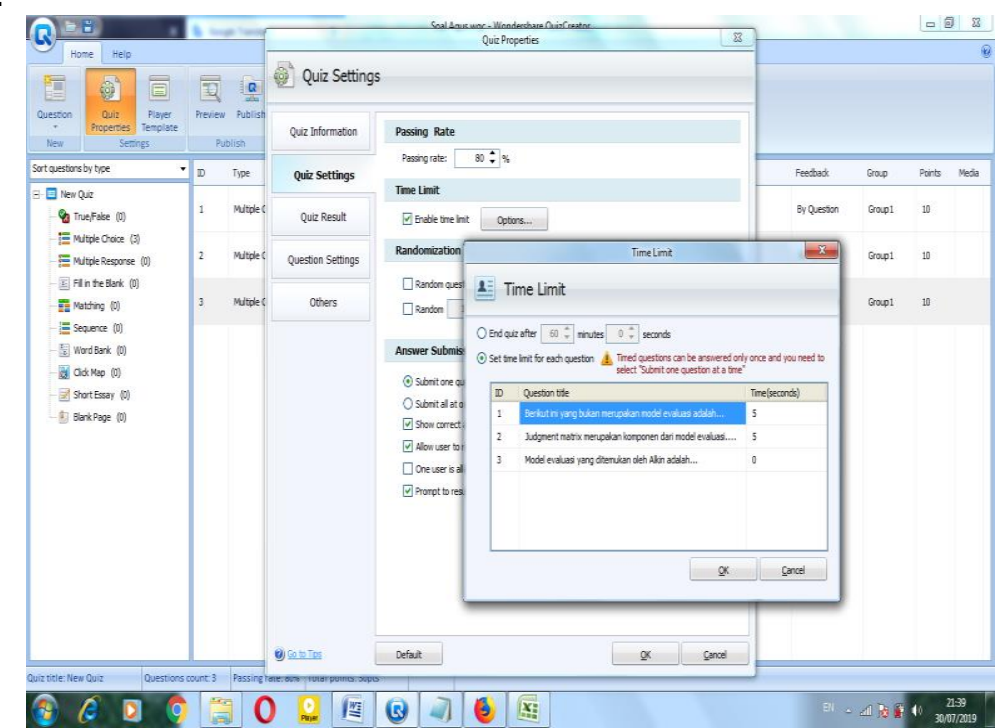

Gambar 13. Pengaturan Waktu Soal dan Passing Grade

\section{5) Publikasi}

Pada umumnya proses publikasi test digital menggunakan aplikasi wondershare dapat dilakukan secara online maupun offline. Publikasi yang dilakukan secara online memungkinkan mahasiswa untuk mengakses test digital secara daring melalui fasilitas internet, sedangkan publikasi secara offline memungkinkan mengakses test digital secara offline tanpa adanya internet. Beberapa tampilan proses pengaturan publikasi secara online maupun offline dapat ditunjukkan pada Gambar 14 dan 15. 


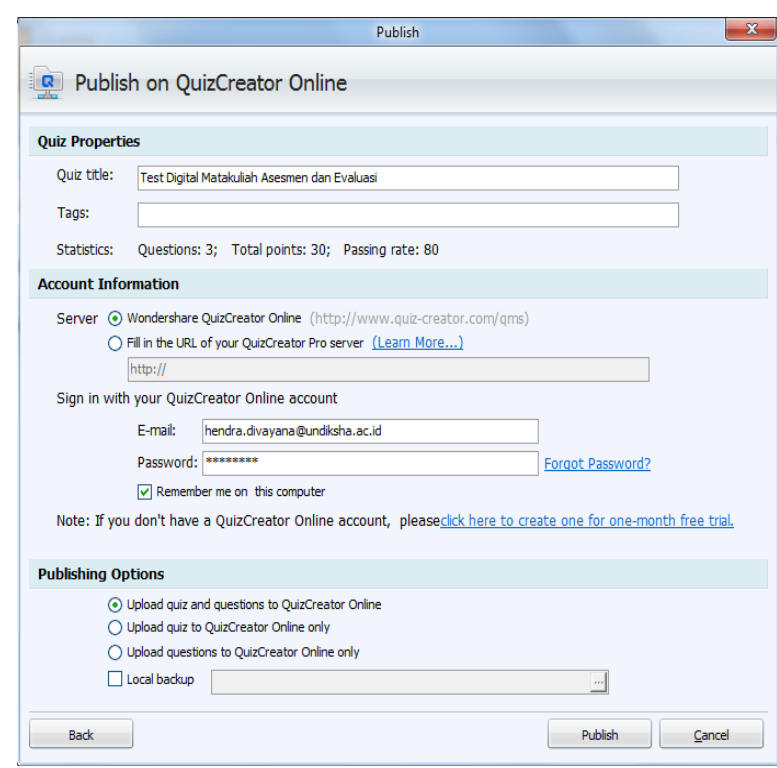

Gambar 14. Publikasi Test Digital Secara Online

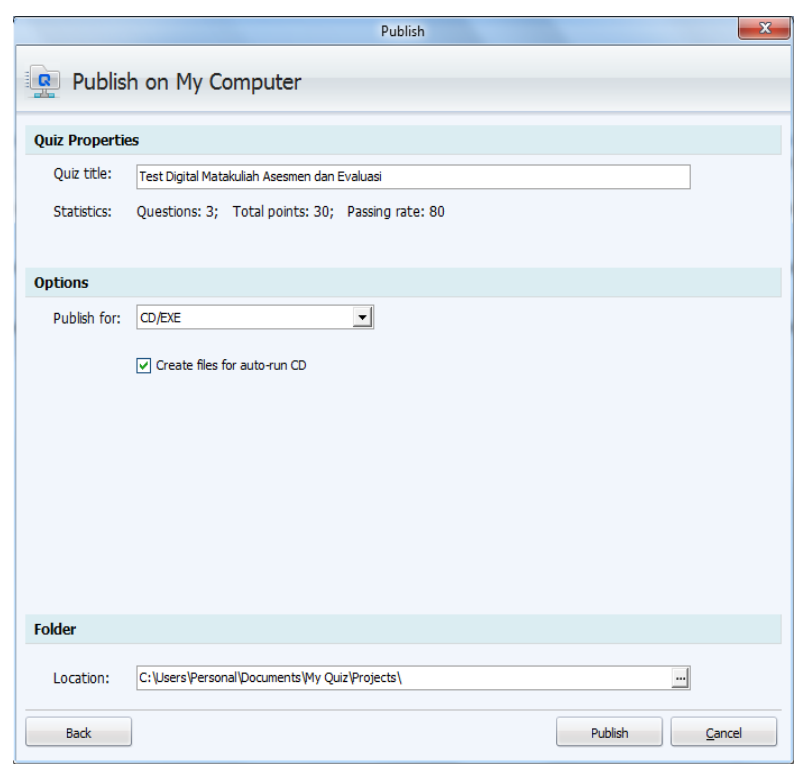

Gambar 15. Publikasi Test Digital Secara Offline

\section{Hasil Uji Coba Awal}

Uji coba awal terhadap soal tes digital matakuliah Asesmen dan Evaluasi menggunakan aplikasi wondershare dilakukan oleh 10 Responden. Adapun hasil uji coba awal tersebut dapat ditunjukkan pada Tabel 5.

Tabel 5. Hasil Uji Coba Awal Terhadap Soal Test Digital Matakuliah Asesmen dan Evaluasi

\begin{tabular}{|c|c|c|c|c|c|c|c|c|}
\hline \multirow{2}{*}{ No } & \multirow{2}{*}{ Responden } & \multicolumn{5}{|c|}{ Butir Pertanyaan } & \multirow{2}{*}{$\Sigma$} & \multirow{2}{*}{$\begin{array}{c}\text { Persentase } \\
\text { Efektivitas (\%) }\end{array}$} \\
\hline & & 1 & 2 & 3 & 4 & 5 & & \\
\hline 1 & $\mathrm{R}-1$ & 5 & 4 & 4 & 5 & 4 & 22 & 88 \\
\hline 2 & R-2 & 4 & 5 & 5 & 4 & 5 & 23 & 92 \\
\hline 3 & $\mathrm{R}-3$ & 4 & 4 & 4 & 5 & 5 & 22 & 88 \\
\hline 4 & R-4 & 4 & 4 & 5 & 4 & 4 & 21 & 84 \\
\hline 5 & R-5 & 5 & 5 & 5 & 4 & 5 & 24 & 96 \\
\hline 6 & R-6 & 4 & 4 & 4 & 5 & 4 & 21 & 84 \\
\hline 7 & R-7 & 4 & 5 & 5 & 5 & 4 & 23 & 92 \\
\hline 8 & $\mathrm{R}-8$ & 4 & 4 & 4 & 4 & 5 & 21 & 84 \\
\hline 9 & R-9 & 5 & 4 & 5 & 5 & 4 & 23 & 92 \\
\hline 10 & $\mathrm{R}-10$ & 4 & 5 & 4 & 4 & 4 & 21 & 84 \\
\hline & & & & & & & Total & 88,4 \\
\hline
\end{tabular}

Berdasarkan hasil uji coba tersebut, tampak bahwa persentase efektivitas sebesar 88 , $4 \%$, hal ini berarti secara umum soal test digital menggunakan aplikasi wondershare termasuk kategori baik dan tidak perlu dilakukan revisi mayor jika ditinjau dari tabel tingkat efektivitas skala lima. Kendatipun soal test digital tersebut sudah baik, namun ada beberapa saran yang diberikan oleh beberapa orang responden untuk penyempurnaan ke arah yang lebih baik terhadap soal test digital matakuliah Asesmen dan Evaluasi. Adapun saran-saran tersebut ditunjukkan pada Tabel 6. 
Tabel 6. Saran Para Responden Terhadap Soal Test Digital Matakuliah Asesmen \& Evaluasi

\begin{tabular}{|c|l|l|}
\hline No & Responden & \multicolumn{1}{c|}{ Saran } \\
\hline 1 & R-1 & $\begin{array}{l}\text { Belum ditemukan adanya cara untuk menilai soal essay, oleh } \\
\text { karena itu perlu dipikirkan cara untuk menilainya. }\end{array}$ \\
\hline 2 & R-7 & Tolong buatkan cara melakukan penilaian terhadap soal essay. \\
\hline 3 & R-10 & $\begin{array}{l}\text { Buatkan teknik menilai khususnya untuk soal berbentuk essay, } \\
\text { sehingga unsur subjektivitas penilaian bisa diminimalisasi. }\end{array}$ \\
\hline
\end{tabular}

Hasil penelitian ini sudah mampu menjadi jawaban terhadap kelemahan dari penelitian sebelumnya yang dilakukan oleh Putrawansyah, Zulkardi, dan Sardianto MS pada tahun 2016, penelitian pada tahun 2017 yang dilakukan oleh Balan, Sudarmin, dan Kustiono, serta penelitian yang dilakukan oleh Meryansumayeka, Virgiawan, dan Marlini pada tahun 2018 yaitu dengan memberikan penjelasan tentang cara pembuatan soal-soal menggunakan aplikasi wondershare sehingga memudahkan para pendidik secara mandiri dalam membuat tes digital yang valid, efektif, praktis, variatif, dan interaktif. Walaupun hasil penelitian ini sudah baik dan mampu menjadi terobosan untuk memecahkan kendala/keterbatasan penelitian sebelumnya, namun penelitian ini juga memiliki kendala dalam hal penilaian untuk soal dalam bentuk essay.

\section{SIMPULAN DAN SARAN}

Soal test digital matakuliah Asesmen dan Evaluasi yang dibuat menggunakan aplikasi wondersahe sudah dapat dikategorikan baik dengan persentase tingkat efektivitas sebesar $88,4 \%$. Aplikasi wondershare dapat digunakan untuk membuat test digital dengan praktis, efektif dan variatif dengan 9 variasi bentuk soal, diantaranya: soal benar-salah, soal pilihan ganda, soal respon ganda, soal mengisi kotak kosong, soal menjodohkan, soal mengurutkan, soal bank kata, soal klik peta/gambar, dan soal essay. Pekerjaan kedepan yang direkomendasikan dalam mengatasi kendala dalam penelitian ini adalah dengan membuat kunci jawaban yang dapat diukur secara kuantitatif dan objektif untuk soal essay.

\section{UCAPAN TERIMAKASIH}

Para penulis mengucapkan terima kasih kepada Bapak Rektor dan Bapak Ketua LPPM Universitas Pendidikan Ganesha yang telah memberi izin kepada para penulis untuk melaksanakan penelitian ini. Penulis juga menyampaikan ucapan terima kasih yang mendalam kepada Dewan Redaksi Jurnal Pendidikan Teknologi dan Kejuruan yang telah memberikan kesempatan dalam mempublikasikan tulisan ini, disamping itu juga penulis juga mengucapkan terima kasih kepada para reviewer yang telah bersedia memberikan masukan/saran yang bersifat membangun dalam penyempurnaan tulisan ini sehingga bisa layak untuk dipublikasikan.

\section{DAFTAR PUSTAKA}

[1] Mintasih, D. (2018). Mengembangkan Literasi Informasi Melalui Belajar Berbasis Kehidupan Terintegrasi PBL Untuk Menyiapkan Calon Pendidik Dalam Menghadapi Era Revolusi Industri 4.0. Elementary: Islamic Teacher Journal, 6(2), 271-290.

[2] Iswan, \& Herwina. (2018). Penguatan Pendidikan Karakter Perspektif Islam Dalam Era Millenial IR. 4.0.Seminar Nasional Pendidikan Era Revolusi, Universitas Muhammadiyah Jakarta, 21-42.

[3] Prasetyo, B., \& Trisyanti,U. (2018). Revolusi Industri 4.0 dan Tantangan Perubahan Sosial. Prosiding SEMATEKSOS 3, Institut Teknologi Sepuluh Nopember,Surabaya,22-27.

[4] Purwandini,D.A., \& Irwansyah. (2018). Komunikasi Korporasi Pada Era Industri 4.0. Jurnal IImu Sosial, 17(1),53-63.

[5] Muslimin, M. (2011). Perkembangan Teknologi Dalam Industri Media. Jurnal Teknik Industri, 12(1),57-64. 
[6] Syamsuar, \& Reflianto. (2018). Pendidikan dan Tantangan Pembelajaran Berbasis Teknologi Informasi di Era Revolusi Industri 4.0. E-Tech: Jurnal IImiah Teknologi Pendidikan, 6(2), 1-13.

[7] Putrawansyah, F., Zulkardi, Sardianto,M.S.(2016). Pengembangan Digital Book Berbasis Android Materi Perpindahan Kalor Di Sekolah Menengah Atas. Indonesian Journal on Networking and Security, 5(4),39-48.

[8] Balan, Y.A., Sudarmin, \& Kustiono. (2017). Pengembangan Model Computer Based Test (CBT) Berbasis Adobe Flash untuk Sekolah Menengah Kejuruan. Innovative Journal of Curriculum and Educational Technology, 6(1),36-44.

[9] Meryansumayeka,Virgiawan, M.D., \& Marlini,S. (2018). Pengembangan Kuis Interaktif Berbasis E-Learning Dengan Menggunakan Aplikasi Wondershare Quiz Creator Pada Mata Kuliah Belajar Dan Pembelajaran Matematika. Journal Pendidikan Matematika, 12(1),29-42.

[10] https://www.wondershare.com/pro/quizcreator.html 